\title{
Hubungan Rinitis Alergi dengan Kejadian Otitis Media Supuratif Kronik
}

\author{
Fatma Diana, T. Siti Hajar Haryuna \\ Departemen THT-KL Fakultas Kedokteran Universitas Sumatera Utara \\ RSUP H. Adam Malik Medan
}

\begin{abstract}
Abstrak
Otitis media supuratif kronik (OMSK) merupakan infeksi telinga tengah yang berat, tidak hanya terjadi di negara berkembang, tetapi juga di negara maju. Prevalensi OMSK di dunia melibatkan 65-330 juta penduduk. Terdapat beberapa teori yang mengungkapkan peran rinitis alergi dalam terjadinya OMSK, teori yang paling banyak digunakan adalah disfungsi tuba eustachius. Penelitian ini merupakan penelitian analitik dengan pendekatan kasus-kontrol tanpa berpasangan. Pengambilan sampel dengan metode consecutive sampling sebanyak 80 responden yang terdiri atas 40 responden OMSK dan 40 responden non-OMSK yang datang ke Poliklinik THT RSUP H. Adam Malik Medan pada bulan Agustus-Oktober 2014. Seluruh responden dilakukan anamnesis, pemeriksaan telinga dan hidung, serta mengisi kuesioner Score for Allergic Rhinitis (SFAR). Hasil penelitian menunjukkan bahwa pada kelompok OMSK, 28 orang (70\%) menderita rinitis alergi dan 12 orang (30\%) tidak menderita rinitis alergi. Pada kelompok non-OMSK 6 orang (15\%) menderita rinitis alergi dan 34 orang (85\%) tidak menderita rinitis alergi. Terdapat hubungan yang signifikan antara rinitis alergi dan kejadian OMSK $(\mathrm{p}<0,001)$. Pasien rinitis alergi memiliki risiko 13 kali lebih besar untuk menderita OMSK dibanding dengan pasien tanpa rinitis alergi (OR=13,222; 95\% IK=4,400-39,732). Probabilitas pasien rinitis alergi untuk menderita OMSK sebesar 92,9\%. Simpulan, terdapat hubungan antara rinitis alergi dan kejadian OMSK. [MKB. 2017;49(2):79-85]
\end{abstract}

Kata kunci: Otitis media supuratif kronik, rinitis alergi, score for allergic rhinitis

\section{Relationship between Allergic Rhinitis and Incidence of Chronic Suppurative Otitis Media}

\begin{abstract}
Chronic suppurative otitis media (CSOM) is a severe infection of the middle ear that is seen not only in developing countries but also in industrialized countries. The prevalence of CSOM in the world involves 65-330 million people. There are some theories regarding the role of allergic rhinitis in CSOM patients with eustachian tube dysfunction theory as the most widely used theory. This was a non-matched case control analytical study on 80 respondents, 40 CSOM respondents and 40 non-CSOM respondents, who were sampled using consecutive sampling method at the Ear-Nose-Throat (ENT) clinic of H. Adam Malik General Hospital in August-October 2014. Anamnesis as well as ear and nose examinations were performed and all respondents fill out the Score For Allergic Rhinitis (SFAR) questionnaire. The results showed that in CSOM group, 28 people (70\%) suffered from allergic rhinitis and 12 people (30\%) did not suffer from allergic rhinitis. In non-CSOM group, the numbers were 6 people (15\%) and $34(85 \%)$, respectively. There was a significant relationship between allergic rhinitis and the incidence of CSOM $(\mathrm{p}<0.001)$. Allergic rhinitis patients have a 13 times greater risk to suffer CSOM than patients without allergic rhinitis (OR=13.222, 95\% CI=4.400-39.732). The probability of patients with allergic rhinitis to suffer CSOM is $92.9 \%$. In conclusion, there is a relationship between allergic rhinitis and the incidence of CSOM. [MKB. 2017;49(2):79-85]
\end{abstract}

Key words: Allergic rhinitis, chronic suppurative otitis media, score for allergic rhintis

Korespondensi: Fatma Diana, dr, Departemen THT-KL Fakultas Kedokteran Universitas Sumatera Utara/Rumah Sakit H. Adam Malik Medan, Jalan.Dr. T. Mansur No.5 Kampus USU, Medan, 20155, E-mail: fatmadiana26@yahoo.com 


\section{Pendahuluan}

Otitis media supuratif kronik (OMSK) merupakan penyakit infeksius kronik tersering di dunia, tidak hanya terjadi di negara berkembang, tetapi juga di negara maju. ${ }^{1}$ OMSK adalah perubahan struktural pada sistem telinga tengah yang memiliki hubungan dengan perforasi membran timpani permanen dalam jangka waktu lebih dari 3 bulan. Secara histologi, OMSK didefinisikan sebagai perubahan mukosa telinga tengah yang ireversibel. ${ }^{2}$ WHO dalam Aboet $^{3}$ menyatakan bahwa prevalensi OMSK di dunia melibatkan 65-330 juta penduduk. Browning dalam Aboet ${ }^{3}$ juga menyatakan bahwa lebih dari $90 \%$ terdapat di negara-negara berkembang seperti Asia Tenggara, Afrika, dan daerah Pasifik di bagian barat. $^{3}$

Terdapat berbagai macam faktor predisposisi kronisitas otitis media. Alergi merupakan salah satu faktor konstitusi yang menyebabkan kronisitas sehingga diduga salah satu faktor risiko penyebab OMSK adalah riwayat rinitis alergi sebelumnya. ${ }^{4}$ Rinitis alergi merupakan kondisi yang memengaruhi keadaan mukosa hidung. Mukosa hidung berlanjut dengan mukosa telinga tengah sehingga perubahan yang terjadi pada mukosa hidung dapat berlanjut ke telinga. Mukosa telinga tengah berasal dari lapisan ektoderm yang sama dengan epitel saluran pernapasan atas dan juga ditemukan memiliki respons kekebalan intrinsik yang sama terhadap stimulus alergen seperti pada saluran hidung, sinus, dan bronkus. ${ }^{5}$

Rinitis alergi merupakan reaksi yang dimediasi oleh IgE. Reaksi ini dibagi menjadi tiga fase, yaitu sensitisasi, early responsse, dan late responsse. Pada fase sensitisasi, alergen yang masuk diproses oleh makrofag dan sel APC sebelum menyajikannya ke sel T-helper yang kemudian berinteraksi dengan limfosit $\mathrm{B}$, kemudian limfosit B berdiferensiasi membentuk IgE. Molekul IgE yang telah terbentuk berikatan dengan reseptornya, reseptor dengan afinitas tertinggi terletak pada sel mast dan basofil. Pada fase early responsse, individu yang telah tersensitisasi jika terpapar dengan alergen yang sama akan langsung memprovokasi reaksi alergi. Cross-linking dari dua molekul IgE yang berdekatan oleh antigen memulai serangkaian kejadian intraseluler yang akan menghasilkan degranulasi sel mast serta pelepasan mediator yang sudah terbentuk dan yang baru dibentuk. Mediator yang sudah terbentuk sebelumnya disimpan di dalam granul sitoplasma seperti histamin, triptase, heparin, serta kondroitin sulfat, sedangkan mediator yang baru dibentuk antara lain platelet activating factor (PAF), prostaglandin (PG), dan leukotrien. Pada fase late responsse, dijumpai peningkatan mediator inflamasi dan gejala dari fase early responsse. ${ }^{2}$

Proses inflamasi tersebut akan meningkatkan aliran darah ke telinga tengah sehingga dapat menurunkan jumlah udara dan mengakibatkan penumpukan tekanan negatif pada rongga telinga tengah. ${ }^{6}$ Jika penanganan pada kondisi ini tidak dilakukan dengan tepat maka akan menyebabkan gangguan telinga tengah seperti gangguan pendengaran, otitis media efusi, dan kronik, serta kolesteatoma. ${ }^{7}$

Laporan penelitian yang mengenai hubungan rinitis alergi dengan kejadian OMSK yang ada di Indonesia saat ini masih sangat terbatas, serta mengacu pada Rencana Strategi Nasional dalam Penanggulangan Gangguan Pendengaran dan Ketulian untuk Mencapai Sound Hearing 2030 -Better Hearing for All maka peneliti tertarik melakukan penelitian hubungan rinitis alergi dengan kejadian OMSK di RSUP H. Adam Malik Medan.

\section{Metode}

Penelitian ini merupakan penelitian analitik dengan pendekatan kasus-kontrol tidak berpasangan yang dilakukan dari bulan Agustus sampai Oktober 2014 di Poliklinik THT-KL RSUP H. Adam Malik Medan. Populasi terjangkau pada penelitian ini adalah pasien OMSK dan non-OMSK yang datang berobat ke Poliklinik THT-KL RSUP H. Adam Malik. Sampel penelitian diambil dengan metode consecutive sampling dengan kriteria inklusi pada kelompok kasus adalah pasien OMSK yang datang ke poliklinik rawat jalan THT dengan keluhan sekret telinga berulang atau pernah selama 3 bulan dan pada pemeriksaan otoskopi didapatkan perforasi membran timpani. Kelompok kontrol adalah pasien tanpa keluhan pada telinga tengah yang datang ke poliklinik rawat jalan THT. Pasien pria atau wanita dengan usia $\geq 10$ tahun dan koperatif serta bersedia mengikuti penelitian dengan menandatangani formulir kesediannya (informed consent). Kriteria eksklusi pada penelitian ini adalah menderita OMA dan OME pada kelompok kasus dan responsden yang tidak mengisi kuesioner dengan lengkap.

Pengumpulan data dilakukan menggunakan anamnesis, pemeriksaan telinga dan hidung, serta pengisian kuesioner Score for Allergic Rhinitis (SFAR) kepada seluruh sampel yang 
memenuhi kriteria inklusi dan tidak termasuk eksklusi. Kuesioner SFAR ini diisi sendiri oleh sampel penelitian, kuesioner ini berisi 8 pertanyaan mengenai rinitis alergi yang terdiri atas empat pertanyaan standar pada gejala hidung yang diambil dari enam pertanyaan ISAAC (International Study of Asthma and Allergies in Childhood) dalam menegakkan rinitis alergi serta dengan penambahan empat pertanyaan mengenai riwayat alergi pada pasien dan keluarga. Total skor dalam kuesioner SFAR dalam rentang $0-16$, pasien rinitis alergi ditegakkan jika skor $\geq 7$ dan pasien non-rinitis alergi dengan skor $<7$. Uji validitas kuesioner tidak dilakukan pada penelitian ini karena sudah dilakukan uji validitas oleh Annesi-Maesano dkk. pada tahun 2002 dengan hasil sensitivitas $74 \%$, spesifisitas $83 \%$, positive predictive value (PPV) $84 \%$, dan negative predictive value (NPV) $74 \%$. Data yang diperoleh diolah dengan program SPSS (statistical product and service solution), selanjutnya dianalisis dengan uji chi-square/ $\mathrm{x}^{2}$. Analisis variabel independen sebagai faktor risiko variabel dependen dengan melihat odds ratio (OR). $\mathrm{OR}>1$ menyatakan bahwa variabel independen merupakan faktor risiko variabel dependen.

\section{Hasil}

Secara umum berdasar atas Tabel 1 dapat digambarkan bahwa dari 40 penderita OMSK jumlah terbanyak perempuan sebanyak 24 orang (60\%). Kelompok usia terbanyak dijumpai pada kelompok usia 10-19 tahun sebanyak 10 orang (25\%), dengan rata-rata usia 35,9 919,327 tahun. Sebagian besar tingkat pendidikan merupakan tamatan SMA sebanyak 19 orang (47\%) dan mayoritas pekerjaan adalah wiraswasta sebanyak 9 orang $(23 \%)$.

Pada Tabel 2, gejala yang terbanyak dikeluhkan adalah telinga berair sebanyak 39 orang (98\%). Keterlibatan telinga pada penderita dari OMSK terbanyak adalah telinga kanan dan bilateral, yaitu masing-masing sebanyak 16 orang $(40 \%)$ seperti yang dapat dilihat pada Tabel 3.

Dari Tabel 4 dapat dilihat bahwa gejala rinitis

Tabel 1 Karakteristik Subjek Penelitian

\begin{tabular}{|c|c|c|}
\hline Variabel & Frekuensi & $\%$ \\
\hline \multicolumn{3}{|l|}{ Jenis kelamin } \\
\hline Laki-laki & 16 & 40 \\
\hline Perempuan & 24 & 60 \\
\hline \multicolumn{3}{|l|}{ Usia (tahun) } \\
\hline $10-19$ & 10 & 25 \\
\hline $20-29$ & 9 & 23 \\
\hline $30-39$ & 6 & 15 \\
\hline $40-49$ & 5 & 12 \\
\hline $50-59$ & 3 & 7 \\
\hline $60-69$ & 5 & 12 \\
\hline $70-79$ & 2 & 5 \\
\hline \multicolumn{3}{|l|}{ Pendidikan } \\
\hline SD & 4 & 10 \\
\hline SMP & 10 & 25 \\
\hline SMA & 19 & 48 \\
\hline Perguruan Tinggi & 7 & 17 \\
\hline \multicolumn{3}{|l|}{ Pekerjaan } \\
\hline Buruh & 4 & 10 \\
\hline IRT & 7 & 17 \\
\hline Pegawai & 4 & 10 \\
\hline Pelajar & 8 & 20 \\
\hline Pensiun & 2 & 5 \\
\hline Wiraswasta & 9 & 23 \\
\hline Tidak bekerja & 6 & 15 \\
\hline
\end{tabular}

Tabel 2 Distribusi Penderita OMSK berdasar atas Gejala Klinis

\begin{tabular}{lcc}
\multicolumn{1}{c}{ Gejala Klinis } & Frekuensi & $\mathbf{\%}$ \\
\hline Telinga berair & 39 & 98 \\
Frekuensi keluarnya sekret & & \\
Terus menerus & 3 & 7 \\
Hilang timbul & 36 & 90 \\
Penurunan pendengaran & 36 & 90 \\
\hline
\end{tabular}


Tabel 3 Distribusi Penderita OMSK berdasar atas Telinga yang Terlibat

\begin{tabular}{lcc}
\hline \multirow{2}{*}{ Telinga yang Terlibat } & $\mathbf{n}$ & OMSK \\
\cline { 2 - 3 } & & \% \\
\hline Unilateral & 16 & 40 \\
Kanan & 8 & 20 \\
Kiri & 16 & 40 \\
Bilateral & 16 & \\
\hline
\end{tabular}

Tabel 4 Distribusi Penderita Rinitis Alergi Berdasar atas Gejala Klinis pada Penderita OMSK

\begin{tabular}{lcc}
\hline Gejala Klinis & Frekuensi & \% \\
\hline Bersin-bersin & 30 & 75 \\
Hidung berair (ingusan) & 30 & 75 \\
Hidung tersumbat & 28 & 70 \\
Mata gatal dan berair & 22 & 55 \\
\hline
\end{tabular}

alergi yang banyak dikeluhkan adalah bersinbersin dan hidung berair, yaitu masing-masing sebanyak 30 orang (75\%). Seperti yang terlihat pada Tabel 5, distribusi penderita rinitis alergi berdasar atas klasifikasi ARIA terbanyak adalah rinitis alergi intermiten sedang-berat sebanyak 10 orang (36\%).

Tabel 6 menunjukkan bahwa berdasarkan hasil uji hipotesis dengan metode chi-square menunjukkan hubungan signifikan antara rinitis alergi dan kejadian OMSK $(\mathrm{p}<0,001)$. Hasil analisis tersebut juga menunjukkan rinitis alergi 13 kali lebih sering ditemukan pada responsden OMSK dibanding dengan responsden non-OMSK (OR=13,222 dan 95\% IK=4,400-39,732). Nilai OR 13,222 dapat di-interpretasikan juga bahwa probabilitas pasien yang mengalami rinitis alergi untuk menderita OMSK sebesar 92,9\%.

\section{Pembahasan}

Secara umum dapat digambarkan bahwa dari 40 responsden OMSK terdapat perempuan 24 orang (60\%), sedangkan laki-laki 16 orang (40\%). Menurut Notoatmodjo dalam Tarigan ${ }^{8}$, hal ini juga menunjukkan bahwa perempuan lebih peduli terhadap kesehatannya dibanding dengan laki-laki sehingga perempuan lebih sering memeriksakan kesehatannya. Bozkus $\mathrm{dkk}^{9}$ melaporkan hasil yang sama, yaitu perempuan pada penderita OMSK sebanyak 43 orang (58\%), yang lebih banyak dibanding dengan laki-laki.

Kelompok usia yang paling banyak dijumpai 10-19 tahun sebanyak 10 orang (25\%) dengan rata-rata usia $35,9 \pm 19,327$ tahun. Hal ini dikarenakan penderita OMSK yang datang ke Poliklinik THT-KL RSUP H. Adam Malik adalah penderita yang mengalami OMA sebelumnya, tetapi tidak menutup kemungkinan penderita tersebut menderita OMSK di bawah usia 10 tahun. Hasil ini hampir sama dengan penelitian Yousuf dkk. ${ }^{10}$ bahwa jumlah tertinggi pasien OMSK pada kelompok usia 11-20 tahun sebanyak 54 orang (54\%). Hasil ini berbeda dengan penelitian Afolabi dkk. ${ }^{11}$ yang melaporkan bahwa pasien OMSK banyak dijumpai pada kelompok usia 1-10 tahun. Anak lebih berisiko menderita

Tabel 5 Distribusi Penderita Rinitis Alergi berdasar atas Klasifikasi ARIA pada Penderita OMSK

\begin{tabular}{lcc}
\hline \multicolumn{1}{c}{ Rinitis Alergi (ARIA) } & Frekuensi (n=28) & n (\%) \\
\hline Intermiten ringan & 8 & 29 \\
Intermiten sedang-berat & 10 & 36 \\
Persisten ringan & 2 & 7 \\
Persisten sedang-berat & 8 & 29 \\
\hline
\end{tabular}


Tabel 6 Hubungan Rinitis Alergi dengan Kejadian OMSKdi RSUP H. Adam Malik Medan

\begin{tabular}{lcccccc}
\hline & \multicolumn{2}{c}{ OMSK } & \multicolumn{2}{c}{ Non-OMSK } & \multirow{2}{*}{ Nilai p } & \multirow{2}{*}{ OR } \\
& $\mathbf{n ~ ( 4 0 )}$ & $\mathbf{\%}$ & $\mathbf{n ~ ( 4 0 )}$ & $\mathbf{\%}$ & & \\
\hline Rinitis alergi & 28 & 70 & 6 & 15 & \multirow{2}{*}{$* 0,001^{*}$} & \multirow{2}{*}{13,222} \\
Non-rinitis alergi & 12 & 30 & 34 & 85 & & \\
\hline
\end{tabular}

OMSK disebabkan oleh anatomi dan fungsi tuba eustachius yang belum sempurna. ${ }^{6}$

Dalam penelitian ini tingkat pendidikan penderita OMSK terbanyak merupakan tamatan SMA. Hal ini dikarenakan pada penelitian ini usia penderita OMSK banyak dijumpai pada usia 10-19 tahun. Jenis pekerjaan terbanyak pada penderita OMSK adalah wiraswasta sebanyak 9 orang.

Gejala klinis yang paling sering dikeluhkan oleh penderita OMSK telinga berair sebanyak 39 orang (98\%). Hasil ini sama dengan penelitian sebelumnya yang dilakukan Yousuf dkk. ${ }^{10}$ yang menyatakan bahwa gejala keluarnya cairan telinga dikeluhkan oleh 100 orang (100\%) yang menderita OMSK dengan kolesteatoma. Tshering dkk. ${ }^{12}$ juga melaporkan hal yang sama bahwa gejala keluar cairan telinga dikeluhkan oleh semua pasien $(100 \%)$ OMSK baik tipe tubotimpani maupun tipe atikoantral.

Dalam penelitian ini dijumpai telinga yang banyak terlibat adalah telinga kanan serta bilateral sebanyak 16 orang masing-masing (40\%), sedangkan pada telinga kiri hanya sedikit dijumpai, yaitu 8 orang (20\%). Keterlibatan kedua telinga/bilateral ini menunjukkan kronisitas dan keparahan penyakit. Dewi dan Zahara ${ }^{13}$ di RSUP H. Adam Malik menunjukkan hasil yang hampir sama, yaitu keterlibatan telinga terbanyak didapati pada telinga kanan sebanyak 9 orang $(39,1 \%)$, diikuti kedua telinga sebanyak 8 orang $(34,8 \%)$, dan telinga kiri paling sedikit dijumpai pada 6 orang $(26,1 \%)$ penyebab insidensi OMSK pada telinga kanan tidak diketahui secara pasti.

Gejala rinitis alergi yang paling banyak dikeluhkan pada kelompok kasus adalah bersinbersin dan hidung berair (ingusan) sebanyak 30 orang $(75 \%)$ masing-masing. Hidung berair (ingusan) menyebabkan perubahan fungsi drainase dan juga aerasi tuba eustachius. Hasil yang sama dilaporkan oleh Orji dkk. ${ }^{14}$ yang menunjukkan bahwa gejala rinitis alergi yang banyak dikeluhkan pasien OMSK adalah hidung berair (ingusan).

Distribusi frekuensi rinitis alergi berdasar atas klasifikasi ARIA pada penderita OMSK paling banyak adalah rinitis alergi intermiten sedang-berat sebanyak 10 dari 28 orang. Hasil ini dikarenakan penderita OMSK banyak dijumpai pada kelompok usia 10-19 tahun sehingga diduga perjalanan penyakitnya tidak panjang. Hasil ini berbeda dengan penelitian sebelumnya yang dilakukan oleh Rambe $\mathrm{dkk}^{7}$ yang menyatakan bahwa $72 \%$ pasien rinitis alergi persisten sedang-berat yang mengalami disfungsi tuba eustachius. Menurut Kurtgoz dkk. ${ }^{15}$ disfungsi tuba eustachius mempunyai peran yang penting dalam patogenesis OMSK.

Dari hasil penelitian ini didapatkan rinitis alergi positif sebanyak 28 orang (70\%) pada kelompok OMSK dan 6 orang (15\%) pada kelompok non-OMSK. Rinitis alergi negatif didapatkan 12 orang (30\%) pada kelompok OMSK serta 34 orang (85\%) pada kelompok non-OMSK. Berdasar atas hasil uji chi-square didapatkan $\mathrm{p}<0,001$ yang berarti terdapat hubungan signifikan antara rinitis alergi dan kejadian OMSK. Dari hasil analisis di atas juga menunjukkan Odds Ratio (OR) sebesar 13,222 $(95 \%$ IK $=4,400-39,732)$ yang memperlihatkan bahwa pasien rinitis alergi memiliki risiko 13 kali lebih besar terjadi OMSK dibanding dengan pasien tanpa rinitis alergi. Nilai OR tersebut dapat juga diinterpretasikan bahwa probabilitas pasien yang mengalami rinitis alergi untuk menderita OMSK sebesar 92,9\%.

Rinitis alergi merupakan kondisi yang memengaruhi keadaan mukosa hidung karena mukosa hidung mempunyai kesamaan dengan mukosa telinga tengah sehingga perubahan yang terjadi pada mukosa hidung dapat berlanjut ke telinga. ${ }^{5}$ Reaksi alergi yang terjadi di mukosa hidung dapat memengaruhi tuba eustachius dan membran timpani melalui beberapa cara: pertama melalui lepasnya berbagai mediator dan sitokin dari sekret hidung yang bermigrasi ke muara tuba eutachius dan cara kedua melalui responss hidung primer, seperti edema mukosa dan hipersekresi hidung. Edema mukosa ini berlanjut sampai ke muara tuba eustachius di nasofaring sehingga menyebabkan obstruksi rongga hidung. Obstruksi rongga hidung juga dapat mengakibatkan perubahan epitel dan sekresi dari mukosa epitel telinga tengah. 
Keadaan tersebut menyebabkan tekanan negatif di nasofaring dan telinga tengah. ${ }^{16,17}$ Tekanan negatif di rongga telinga tengah ini menyebabkan retraksi pada membran timpani. ${ }^{9}$

Penelitian Lasisi dkk. ${ }^{18}$ di Nigeria yang melakukan tes cukit kulit, pemeriksaan cairan hidung, dan pemeriksaan ELISA pada sekret telinga menunjukkan hasil yang sama bahwa didapatkan peran alergi dalam terjadinya OMSK. Gorgulu dkk. ${ }^{19}$ juga melaporkan hal yang sama bahwa terdapat perbedaan yang signifikan antara kadar IgE pada pasien OMSK dan pasien kontrol $(p=0,031)$ serta terdapat perbedaan yang signifikan antara tingkat positivitas alergi pasien OMSK dibanding dengan pasien kontrol $(p=0,042)$. Hal ini mungkin lebih mudah untuk menjelaskan prevalensi tinggi hipersensitivitas yang dimediasi oleh IgE dan rinitis alergi pada orang dewasa dengan OMSK.

Dalam studi meta-analisis yang dilakukan oleh Zhang dkk. ${ }^{20}$ telah melaporkan bahwa dari berbagai faktor risiko yang ada, alergi atau keadaan atopi merupakan salah satu faktor risiko yang dapat meningkatkan otitis media kronik $(\mathrm{p}<0,001 ; \mathrm{OR}=1,36)$. Bozkus dkk. ${ }^{9}$ juga melaporkan hal yang sama bahwa terdapat perbedaan yang signifikan kelompok OMSK dan non-OMSK dangan parameter-parameter alergi pada hidung, hal ini menunjukkan peran rinitis alergi dalam kejadian OMSK.

Hasil ini berbeda dengan penelitian oleh Bakhshaee dkk. ${ }^{1}$ di Iran yang sudah melakukan pembagian kuesioner rinitis alergi, tes cukit kulit serta total serum IgE didapatkan rinitis alergi dialami oleh 20 orang $(29,41 \%)$ pada kelompok OMSK dan 41 orang $(22,28 \%)$ pada kelompok non-OMSK. Rinitis alergi lebih banyak ditemukan pada kelompok OMSK dibanding dengan kelompok non-OMSK, namun perbedaan antara kedua kelompok ini secara statistik tidak signifikan $(p=0,241)$.

Simpulan, terdapat hubungan antara rinitis alergi dan OMSK di RSUP H. Adam Malik Medan. Pasien rinitis alergi memiliki risiko 13 kali lebih besar menderita OMSK dibanding dengan pasien tanpa rinitis alergi. Probabilitas pasien yang mengalami rinitis alergi untuk menderita OMSK sebesar 92,9\%.

\section{Daftar Pustaka}

1. Bakhshaee $M$, Rajati $M$, Fereidouni $M$, Khadivi E, Varasteh A. Allergic rhinitis and chronic suppurative otitis media. Eur Arch Otorhinolaryngol. 2011;268(1):87-91.
2. Snow JB, Wackym PA, penyunting. Ballenger's otorhinolaryngology head and neck surgery. Edisi ke-17. India: BC Decker Inc; 2009.

3. Aboet A. Radang telinga tengah menahun. Pidato pengukuhan Jabatan Guru Besar Tetap Bidang Ilmu Kesehatan Telinga Hidung Tenggorok Bedah Kepala Leher. Medan: FK USU; 4 Agustus 2007.

4. Utami TF, Sudarman K, Rianto BUD, Christanto A. Rinitis alergi sebagai faktor resiko otitis media supuratif kronis. CDK. 2010;179:425-9.

5. Murthy A, Meghna P. Allergic rhinitis and its effect on middle ear pressure. Nat J Otorhinolaryngol Head Neck Surg. 2013; 1(10):8-9.

6. Skoner AR, Skoner KR, Skoner DP. Allergic rhinitis, histamine, and otitis media. Allergy Asthma Proceedings. 2009;30(5):470-81.

7. Rambe AYM, Fadhlia, Munir D, Haryuna TSH, Eyanoer PC. Hubungan rinitis alergi dan disfungsi tuba eustachius dengan menggunakan timpanometri. Oto Rhino Laryngolica Indonesiana. 2013;43(1):80-9.

8. Tarigan J. Pengaruh faktor predisposisi masyarakat Tionghoa terhadap pemanfaatan pelayanan kesehatan di Puskesmas Panipahan Kecamatan Pasir Limau Kapas, Kabupaten Rokan Hilir, Provinsi Riau [tesis]. Medan: Universitas Sumatera Utara; 2010.

9. Bozkus F, Bozan N, Iynen I, Sakin YF, Kiris M. Analysis of sinonasal, pharyngeal and allergy-related risk factors for chronic suppurative otitis media. Acta Medica Mediterranea. 2013;29:47-52.

10. Yousuf M, Majumder KA, Kamal A, Shumon AM, Zaman Y. Clinical study on chronic suppurative otitis media with cholesteatoma. Bangladesh J Otorhinolaryngol. 2011;17(1): 42-7.

11. Afolabi OA, Salaudeen AG, Ologe FE, Nwabuisi C, Nwawolo CC. Pattern of bacterial isolates in the middle ear discharge of patientswith chronic suppurative otitis media in a tertiary hospital in Northcentral Nigeria. African Health Sci. 2012;12(3):362-8.

12. Tshering P, Joarder MAH, Chowdhury MA, Saha KL. Clinicopathological study on CSOM: a comparison between tubotympanic and atticoantral variety. Bangladesh J Otorhinolaryngol. 2012;18(2):138-44.

13. Dewi NP, Zahara D. Gambaran pasien otitis media supuratif kronik (OMSK) di RSUP H. Adam Malik Medan. E-Journal FK USU. 2013;1(2):1-6.

14. Orji FT, Dike BO, Oji O. Determinants of non- 
healing ear discharge in chronic suppurative otitis media in a developing country. Eur Arch Otorhinolaryngol. 2015;272(10):1-6.

15. Kurtgoz S, Kokten N, Tekin M. Assessment of nasal airway resistances and nasal mucociliary activities of patients with unilateral chronic otitis media by acoustic rhinometryand saccharin test. Acta OtoLaryngologica. 2014;134:898-903.

16. Pelikan Z. Audiometric changes in chronic secretory otitis media due to nasal allergy. Otol Neurotol. 2009;30(7):868-75.

17. Ural A, Minovi A, Cobanoglu B. Upper airway obstructions and chronic otitis media: a clinical study. Am J Otolaryngol Head Neck
Med Surg. 2014;35:329-31.

18. Lasisi AO, Arinola OG, Olayemi O. Role of elevated immunoglobulin $\mathrm{E}$ levels in suppurative otitis media. Ann Trop Paediatr. 2008;28:123-7.

19. Gorgulu O, Ozelci M, Ozdemir S, Yasar M, Olgun MK, Arikan OK.The role of allergy in the pathogenesis of chronic suppurative otitis media. J Int Advanced Otol. 2012;8(2):27681.

20. Zhang Y, Xu M, Zhang J, Zeng L, Wang Y, Zheng QY. Risk factors for chronic and recurrent otitis media-A meta-analysis. PloS One. 2014;9(1):e8639. 